\title{
IPTEKS PROSES PENJUALAN MOBIL DI PT HASJRAT ABADI MANADO
} CABANG TENDEAN

\author{
Tommy L.H. Tumalun ${ }^{1}$, Dicky Triwellly ${ }^{2}$, Yehezkiel Balau ${ }^{3}$, Heince R.N. Wokas ${ }^{4}$ \\ 1,2,3,4 Jurusan Akuntansi, Fakultas Ekonomi dan Bisnis, Universitas Sam Ratulangi, Kampus Unsrat, Manado, \\ 95115, Indonesia \\ email : Tommy.tumalun17@gmail.com
}

\begin{abstract}
Industrial development in Indonesia is growing rapidly, especially in the automotive sector. PT Hasjrat Abadi is one of the automotive industries that is in great demand by the public, because PT Hasjrat Abadi always has innovation and quality in every product. PT Hasjrat Abadi holds Car and Motorcycle companies namely Toyota and Yamaha. PT Hasjrat Abadi Manado branch Tendean is a branch that has a strategic location, so many people buy cars in this branch. The process of purchasing a Car through a field sales or sales counter. Purchases can be made with cash or credit payments.
\end{abstract}

Keywords: Automotive industry, innovation, product quality, sales, credit, and cash.

\section{PENDAHULUAN}

Di era perkembangan teknologi dan industry banyak mengalami perubahan yang signifikan. Dengan adanya inovasi dan kreativitas perusahaan akan mampu bertahan dalam persaingan dunia bisnis di Indonesia. Oleh karena itu perusahaan harus mempunyai banyak ide kreativitas yang baru untuk menunjukan keunggulan dari perusahaan lainya. Salah satu perusahaan yang berkembang pesat yaitu di bidang otomotif baik kendaraan beroda dua dan beroda empat.

PT hasjrat Abadi merupakan salah satu perusahaan di bidang otomotif terbesar di indonesia. PT hasjrat abadi memegang perusahaaan mobil dan motor, yaitu Toyota dan Yamaha. PT hasjrat abadi memiliki citra merek dan produk yang berkualitas sehingga mampu bersaing di dunia otomotif, dilihat dari segi banyak nya kendaraan di jalan raya yang keluaran dari toyota dan yamaha,. PT hasjrat Abadi manado Cabang Tendean merupakan salah satu cabang yang mengeluarkan banyak mobil untuk para pengguna toyota di Sulawesi Utara.

PT Hasjrat Abadi Manado cabang Tendean memiliki tempat yang sangat strategis. Yang terletak di jalan boulvard manado. Terletak di daerah pertokoan dan Mall di manado, sehingga costumer lebih memilih di PT hasjrat Abadi Manado cabang Tendean. Pembelian mobil melalui para sales lapangan atau para sales counter. Ketika pemesanan sudah ada maka akan di proses sampai keluarnya mobil.

\section{TINJAUAN PUSTAKA}

Citra Merek. Menurut Aaker dan Biel (1993) citra merek yaitu suatu perilaku konsumen terhadap merek barang dalam dunia pasar. Hal tersebut dapat timbul atau tercipta dari pengalaman pribadi orang maupun dari orang lain, baik dari media social atau interaksi sehari-hari. Menurut Schiffman dan Kanuk (2007) "Citra merek adalah sekumpulan asosiasi mengenai suatu merek yang tersimpan dalam benak atau ingatan konsumen”.

Kualitas Produk. Menurut Kanuk dan Schiffman (2007), kualitas produk adalah suatu keunggulan output dari sebuah perusahaan yang dapat menjadi ciri khas dalam perusahaan tersebut, sehingga konsumen atau masyarakat dapat mengenalinya dengan mudah. Menurut Kotler dan Amstrong, (2008), kualitas produk adalah strategi utama dalam 
sebuah proses menghasilkan produk untuk di jual di pasaran. Dengan kualitas produk yang baik perusahaan akan lebih di kenal dalam pasar. Kualitas produk dapat meliputi ketahanan, ketepatan, tahan lama, kemudahan, dan gampang di gunakan.

Sales. Penjualan menurut Basu Swasta (2001:1) merupakan suatu ilmu pengatahuan dan seni yang mempengaruhi pribadi individu yang dilakukan oleh pihak penjual kepada pihak membeli untuk membeli suatu barang dan jasa yang tawarkan. Penjualan menurut Thamrin Abdullah dan Francis Tantri (2016:3) Penjualan merupakan suatu kegiatan promosi dan promosi juga salah satu hal yang berkaitan dengan keseluruhan sistem pemasaran. Sales (Penjualan) adalah kegiatan dalam perusahaan yang menjual produk barang atau jasa. Dalam penjualan membutuhkan dua pihak yang saling berhubungan yaitu penjual dan pembeli. Terjadinya penjualan ketika pembeli/konsumen sepakat membeli barang/jasa yang diinginkan dengan harga yang telah disepakati. Dengan adanya penjualan perusahaan akan menerima laba. Semakin banyak penjualan dari perusahaan maka laba juga akan semakin banyak.

\section{METODE DAN TEKNIK PENERAPAN IPTEKS}

\subsection{Metode Penerapan Ipteks}

Metode IPTEKS yang akan diterapkan yaitu mengimplementasikan proses penjualan mobil di PT hasjrat abadi menurut prosedur dalam sistem informasi akuntansi penjualan yang berlaku dan di tetapkan oleh perusahaan PT. hasjrat Abadi Toyota Manado Cabang Tendean.

\subsection{Teknik Penerapan Ipteks}

Teknik penerapan IPTEKS yang digunakan penulis yaitu melakukan pengamatan dan pengecekan data terhadap proses penjualan mobil di PT Hasjrat Abadi Manado Cabang tendean menurut prosedur dalam sistem informasi akntansi penjualan yang berlaku.

\section{PEMBAHASAN}

\subsection{Gambaran Objek Penerapan Ipteks}

PT Hasjrat abadi mulai menjalankan peluang bisnis dan membentuk citra bisnis pertamanya di lini pasar baru, yaitu dengan menghasilkan berbagai macam produk. Produk yang ditawarkan pada saat itu meliputi alat elektornik, pintu kayu, semen, serta kendaran roda empat. Seiring berjalannya waktu, pada tahun 1965 perusahaan ini mulai berkembang menjadi distributor eklusif sepeda motor Yamaha di Manado, dan mulai mengembangkan bisnis usahanya sampai ke wilayah-wilayah sekitarnya. Sehingga pada tahun 1979 PT Hasjrat Abadi menjalin kerja sama dengan Toyota dalam hal untuk menjadi salah satu dari lima mitra distribusi usaha yang resmi di Indonesia. Dengan memegang kendali atas distribusi eksklusif yang meliputi wilayah Maluku, papua, Sulawesi tengah dan utara. Pada tahun yang sama PT Hsajrat Abadi mendirikan salah satu mitra layanan purna jual yaitu CV Kombos Manado demi untuk memperoleh kelengkapan atas fasilitas penjualan yang akan dilakukan. Hingga sampai saat ini PT Hasjrat Abadi sendiri sudah memiliki jumlah 2200 staf yang sudah bekerja, serta mengkhusukan usahanya dalam bidang pejualan, service dan pembiayaan.

\subsection{Pembahasan}

PT. Toyota Hasjrat Manado cabang tendean menyediakan berbagai macam mobil bermerek. Contoh mobil yang di jual : AGYA, AVANZA, CALYA, RUSH, YARIS, FORTUNER, HILUX, CAMRY, INNOVA, CHR, HIACE, COROLLA, VIOS, DYNA, ALPHARD, VELLFIRE, ETIOS, dan SIENTA. Pembelian setiap mobil melalui Sales Lapangan atau Sales Counter. Penjualan mobil dapat dilakukan dengan pembayaran secara tunai maupun kredit. Berikut proses penjualan yang di gunakan PT Hasjrat Abadi Toyota Manado Cabang Tendean : 


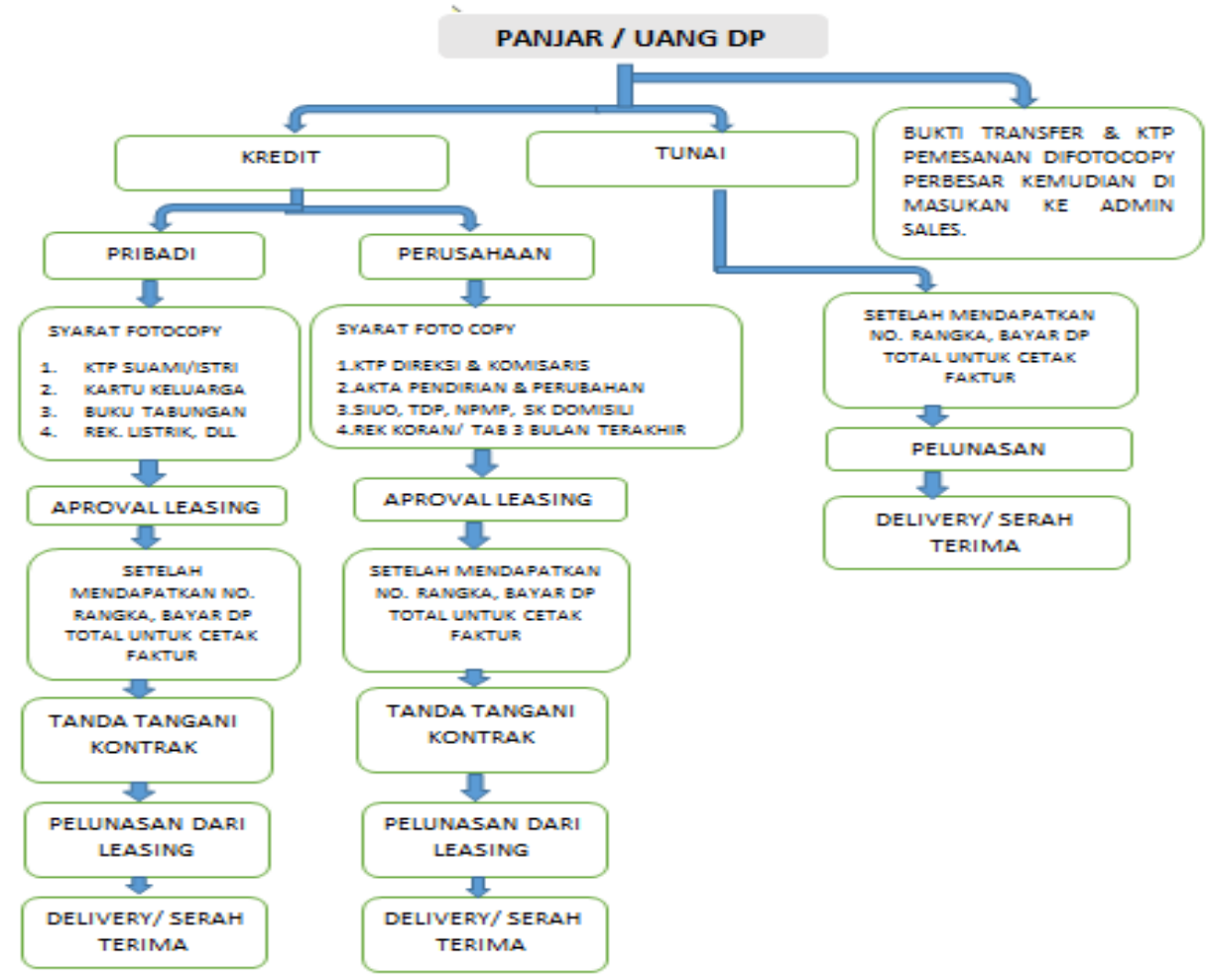

Proses Pembelian mobil di awali dengan menyetor uang DP atau panjar, baik itu pembelian secara tunai maupun secara kredit. Setelah itu, bukti transfer dan KTP pemesan di fotocopy perbesar kemudian di masukan ke admin sales. Setelah membayar uang DP/panjar, kemudian ada dua proses yang harus di lalui, yaitu pembelian secara kredit ataupun tunai. Jika pembelian secara tunai, prosesnya adalah setelah melakukan pembayaran uang DP atau panjar, cukup hanya dengan menunggu untuk mendapatkan nomor rangka, kemudian bayar DP total untuk cetak faktur, setelah itu melakukan pelunasan harga untuk kemudian melakukan serah terima barang.

Berbeda dengan pembelian secara tunai, pembelian secara kredit dibedakan berdasarkan si pembeli, apakah pembelian dilakukan secara pribadi ataupun pembelian oleh perusahaan. Yang membedakan Pembelian kredit secara pribadi dan perusahaan ada pada syarat pembeliannya. Dimana, jika pembelian kredit dilakukan secara pribadi, syarat yang harus di lengkapi adalah ; dengan melengkapi fotocopy KTP suami/istri, Kartu keluarga, Buku tabungan, Rek. Listrik/Air/telepon. Sedangkan pembelian secara kredit oleh perusahaan, syarat yang harus di lengkapi adalah, KTP Direksi/komisaris, Akta pendirian dan perubahan, SIUO, TDP, NPMP, SK domisili dan rekening koran / tabungan selama 3 bulan.

Setelah melengkapi syarat-syarat tersebut, baik itu pembelian kredit secara pribadi maupun perusahaan, sama-sama mempunyai proses yang sama, yakni, setelah melengkapi syarat pembelian, kemudian dilakukan Aproval Leasing, kemudian menunggu nomor rangka, dan setelah mendapat nomor rangka kemudian melakukan pembayaran DP total untuk cetak faktur, setelah itu dilakukan penandatanganan kontrak kemudian dilanjutkan dengan pelunasan dari leasing setelah itu melakukan serah terima kendaraan.

\section{KESIMPULAN DAN SARAN}

\subsection{Kesimpulan}

Pada proses pembelian mobil di PT Hasjrat Abadi Manado Cabang tendean dilakukan dengan pembayaran tunai atau kredit. Tata cara pembelian pribadi berbeda dengan pembelian 
perusahaan atau instansi pemerintahan. Proses pembelian tunai lebih cepat di banding dengan pembelian secara kredit.

\subsection{Saran}

PT Hasjrat dapat meningkatkan pelayanan dan kenyamanan sehingga ketika proses pembelian mobil di PT Hasjrat abadi dapat memuaskan setiap costumer yang ada.

\section{DAFTAR PUSTAKA}

Aaker dan Biel. 1993. Brand Equity and Advertising : Advertising's Role in

Abdullah, Thamrin dan Francis Tantri. 2012. Manajemen Pemasaran. Depok : PT Raja Grafindo Persada

Basu Swastha, 2001. Manajemen Pemasaran Modern; Yogyakarta: BPFE

Danu Prihatmono, Analisis tentang Sistem Penjualan pada Dealer Solindo Motor di Wonogiri. http://eprints.uns.ac.id/10703/1/67862206200907151.pdf

Hasjrat Abadi, "Penjualan". 26 Oktober 2018. https://id.wikipedia.org/wiki/Penjualan

Hasjrat Abadi, "Sejarah". 26 Oktober 2018. https://www.hasjrat.co.id/profil/4/sejarah

Hestanto, 2017, “ Citra Merek”. 26 Oktober 2018. https://www.hestanto.web.id/citra-merekbrand- menurut-para-ahli

Hestanto , 2017, “ Kualitas Produk”. 26 Oktober 2018. https://www.hestanto.web.id/kualitasproduk/

Kotler, Philip and Gary Armstrong. 2008. Prinsip-prinsip Pemasaran. Edisi 12. Jilid 1. Jakarta: Erlangga.

Schiffman dan kanuk, 2007. Perilaku Konsumen, Edisi Kedua, Jakarta: PT. Indeks Gramedia.

Tri haryanti, 2014. Analisis Realisasi Penjualan Mobil pada PT. Agung Automall Sekupang https://repository.polibatam.ac.id/uploads/207029-20170808010804.pdf

Volvo Sihombing, Sistem Informasi Penjualan Mobil Suzuki di Dealer Bagian Batu. Jurnal Sistemasi. Volume 7, Nomor 2, Mei 2018 : 113-119. 